\title{
A 2020 centenary perspective on neuromuscular disorders
}

\author{
Stephen A Goutman 조 , Brian Christopher Callaghan ํㅜ, Eva Feldman
}

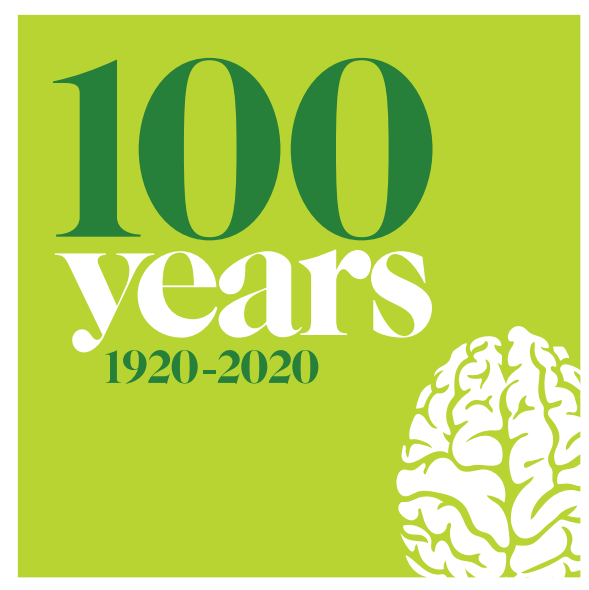

Genetic diagnoses and gene-based therapies have transformed our approach to neuromuscular disorders and created new therapies to treat previously incurable diseases

\section{GENETIC DIAGNOSES AND}

\section{GENE-BASED THERAPIES HAVE}

TRANSFORMED OUR APPROACH TO NEUROMUSCULAR DISORDERS AND CREATED NEW THERAPIES TO TREAT PREVIOUSLY INCURABLE DISEASES

In August 1921, the Journal of Neurology, Neurosurgery and Psychiatry (JNNP) published a case of recurrent hypertrophic neuritis, ${ }^{1}$ which detailed the clinical course of a patient with a likely inherited neuropathy. Although unknown in 1921, this article foreshadowed the critical role that genetics would play in altering the course of neuromuscular diseases in the next 100 years. In fact, 98 years later JNNP published a review on peripheral neuropathy in complex inherited diseases. ${ }^{2}$ As a group of disorders, neuromuscular diseases include entities that affect muscle, the neuromuscular junction, peripheral nerves, nerve roots and motor neurons. At each location, genetic alterations can result in severe disease, resulting in mild-to-severe disability for those carrying mutations. The progress made in our understanding of the genetic aetiology of neuromuscular diseases in the

Neurology, University of Michigan, Ann Arbor, Michigan, USA

Correspondence to Dr Eva Feldman, Ann Arbor, Michigan, USA; efeldman@umich.edu last 100 years is remarkable. When JNNP first began publishing articles the structure of DNA was unknown, and today we have effective gene-targeted therapies that alter the course of multiple neuromuscular diseases. One year ago, we were challenged to consider the 'most important or transformative development in neurology' in the past 100 years and how JNNP contributed to this achievement given its broad scope. ${ }^{3}$ To our surprise, no nomination for neuromuscular disorders made the final list. ${ }^{4}$ Therefore, we wish to put forth a nomination for neuromuscular disorders. All articles cited for this nomination are published in JNNP. We contend the subspeciality of neuromuscular disorders leads the neurologic community in the most important achievements in the last 100 years: discovering the genetic aetiology of previously untreatable neuromuscular disorders and turning these discoveries into therapies.

\section{DESCRIBE, DECIPHER, DETECT}

So how did we get here? Quite literally by standing on the shoulders of giants. We have relied on the dedication of pioneers that have come before us to describe and detail the diseases under this umbrella. Their detailed descriptions, such as those by Anita Harding and Peter (PK) Thomas describing Kennedy's disease and inherited neuropathies, ${ }^{5} 6$ have helped shape our understanding of variability within the same diseases. It is only by understanding phenotypes, whether they be based on history, examination or pathology, that patients with the same disease can be grouped into common entities. These broad groupings then become important as they provide clues to additional features that alter disease. For example, consider spinal muscular atrophy (SMA). Children with SMA type 1 have the same genetic mutation in survival motor neuron protein (SMN) as children with SMA type 2, but the expression of the SMN2 gene determines disease phenotype. The wide range of phenotypes from early to later onset serve as the cornerstone for therapeutic development. ${ }^{7}$ These early pioneers that steadfastly catalogued the range of signs and symptoms, and did so in a time prior to computerised disease registries, were able to create the groupings of patients needed to begin deciphering the underlying genetic causes of disease. These groupings were in place as technology moved from linkage analysis to Sanger sequencing to next generation sequencing, creating the clinical framework to detect the underlying defects in the genetic code.

\section{GENE-BASED THERAPEUTIC TARGETS}

At this writing, the GeneTable of Neuromuscular Disorders (http://www. musclegenetable.fr/index.html) lists 587 genes associated with 1042 disorders. These include 97 entries for hereditary motor sensory neuropathies, 50 for muscular dystrophies, 35 for congenital muscular dystrophies, 44 for congenital myopathies, 30 for other myopathies, 19 for distal myopathies, 6 for myotonic syndromes, 8 for ion channel muscle disorders, 29 for metabolic myopathies, 71 for motor neuron disorders and 32 for congenital myasthenic syndromes. These all represent potential targets for genebased treatments. ${ }^{8}$

Knowledge of these genes and function enabled the development and recent approval of drugs for SMA, specifically the antisense oligonucleotide nusinersen ${ }^{9}$ and the gene therapy onasemnogene, ${ }^{8}$ both of which led to not only the achievement of motor milestones in children with SMA, but also a reduction in mortality for this previously universally fatal condition. These critical clinical achievements have led to mandatory SMA gene testing in over half of the USA and has turned a lethal neuromuscular disorder in infants into a treatable possibly curable condition. Similarly, transthyretin (TTR) amyloidosis began with identification of the underlying genetic cause and pathophysiology and evolved into a disease with multiple gene-based therapies. We have antisense oligonucleotide (ASO) and RNA interference medications that can halt or even reverse the neuropathy experienced by these patients. ${ }^{10}$ SMA and TTR amyloidosis are only two examples of neuromuscular therapeutics. There are currently a large number of gene therapy studies listed on ClinicalTrials.gov ranging from those for X-Linked Myotubular Myopathy (NCT03199469), Limb 
Girdle Muscular Dystrophy (LGMD) Type 2C (NCT01344798), LGMD2D (NCT01976091) and Becker Muscular Dystrophy and Sporadic Inclusion Body Myositis (NCT01519349), to name a few. These gene therapies are complimented by ASO studies for Duchenne Muscular Dystrophy (NCT00159250), Myotonic Dystrophy Type 1 (NCT02312011), SOD1 Amyotrophic Lateral Sclerosis (NCT02623699) and C9ORF72 ALS (NCT04288856). Neuromuscular disorders leads the neurological community in using our new understanding of genetic inheritance to develop and implement effective therapies.

\section{THE NEXT 100 YEARS}

What do the next 100 years hold? We will leverage the knowledge gained by treating multiple patients with the same mutation with the same drug to treat one patient with one genetic defect for a true personalised approach to neuromuscular diseases. Further, given the complexity of some neuromuscular diseases, we will harness the availability of new technology and large cohorts to find the polygenic causes of diseases where previously monogenetic causes were elusive. Next, we will better understand the interactions of our genes with the world around us-the exposome. ${ }^{11}$ This deeper understanding will in turn allow better drug targeting for multiple genes as well as any genes that are impacted by environmental exposures, a particularly relevant topic as our world experiences the COVID-19 pandemic. These therapies bring hope and allow us to envision a future where neurologists both diagnose and provide life-altering therapies for neuromuscular patients of all ages.

\section{HAVE YOUR SAY}

JNNP is asking readers to choose the most important or transformative development in neurology, neurosurgery or psychiatry in the past 100 years. To cast your vote visit our website at https://jnnp. bmj.com/pages/jnnp-100-a-centenary-ofpublishing-neuroscience-achievement/. Voting closes on 15 August 2020.

Contributors $\mathrm{SAG}, \mathrm{BCC}$ and $\mathrm{EF}$ were involved in all aspects of the Editorial.

Funding Support was provided by NIH NIEHS K23ES027221 (SAG) and the NeuroNetwork for Emerging Therapies at University of Michigan (BCC and ELF).

Competing interests SAG consults with Biogen and ITF Pharma. He also serves on an ALS DSMB via Watermark Research Partners. BCC consults for a PCORI grant, DynaMed, the Immune Tolerance Network and performs medical legal consultations including consultations for the Vaccine Injury Compensation Program.

Patient consent for publication Not required.

Provenance and peer review Commissioned; internally peer reviewed.

\section{(2) OPEN ACCESS}

Open access This is an open access article distributed in accordance with the Creative Commons Attribution Non Commercial (CC BY-NC 4.0) license, which permits others to distribute, remix, adapt, build upon this work non-commercially, and license their derivative works on different terms, provided the original work is properly cited, appropriate credit is given, any changes made indicated, and the use is non-commercial. See: http:// creativecommons.org/licenses/by-nc/4.0/.

(c) Author(s) (or their employer(s)) 2020. Re-use permitted under CC BY-NC. No commercial re-use. See rights and permissions. Published by BMJ.

Check for updates
To cite Goutman SA, Callaghan BC, Feldman E. J Neurol Neurosurg Psychiatry 2020;91:791-792.

Received 19 June 2020

Accepted 22 June 2020

J Neurol Neurosurg Psychiatry 2020;91:791-792. doi:10.1136/jnnp-2020-324327

\section{ORCID iDs}

Stephen A Goutman http://orcid.org/0000-0001-87806637

Brian Christopher Callaghan http://orcid.org/00000002-8885-6748

Eva Feldman http://orcid.org/0000-0002-9162-2694

\section{REFERENCES}

1 Nattrass FJ. Recurrent hypertrophic neuritis. J Neurol Psychopathol 1921:2:159-65.

2 Rossor AM, Carr AS, Devine H, et al. Peripheral neuropathy in complex inherited diseases: an approach to diagnosis. J Neurol Neurosurg Psychiatry 2017:88:846-63.

3 Kiernan MC. Milestones. J Neurol Neurosurg Psychiatry 2019;90:1189.

4 Kiernan MC. The Journal of Neurology, Neurosurgery and Psychiatry centenary milestone award 2020. J Neurol Neurosurg Psychiatry 2020:91:677.

5 Harding AE, Thomas PK, Baraitser M, et al. X-Linked recessive bulbospinal neuronopathy: a report of ten cases. J Neurol Neurosurg Psychiatry 1982;45:1012-9.

6 Harding AE, Thomas PK. Autosomal recessive forms of hereditary motor and sensory neuropathy. J Neurol Neurosurg Psychiatry 1980:43:669-78.

7 Wadman RI, Stam M, Gijzen M, et al. Association of motor milestones, SMN2 copy and outcome in spinal muscular atrophy types 0-4. J Neurol Neurosurg Psychiatry 2017:88:365-7.

8 Kariyawasam D, Alexander IE, Kurian M, et al. Great expectations: virus-mediated gene therapy in neurological disorders. J Neurol Neurosurg Psychiatry 2020;91:849-60

9 Farrar MA, Teoh HL, Carey KA, et al. Nusinersen for SMA: expanded access programme. J Neurol Neurosurg Psychiatry 2018:89:937-42.

10 Sekijima Y, Transthyretin SY. Transthyretin (ATTR) amyloidosis: clinical spectrum, molecular pathogenesis and disease-modifying treatments. J Neurol Neurosurg Psychiatry 2015;86:1036-43.

11 Goutman SA, Boss J, Patterson A, et al. High plasma concentrations of organic pollutants negatively impact survival in amyotrophic lateral sclerosis. J Neurol Neurosurg Psychiatry 2019;90:907-12. 